\title{
Occurence, Identification and Phylogenetic Analysis of Fusarium proliferatum on Bean Seed (Phaseolus vulgaris L.) in Serbia
}

\author{
Maja Ignjatov ${ }^{1}$ Tatjana Popović ${ }^{2}$ Dragana Milošević1 $\cdot$ Mirjana Vasić1 \\ Zorica Nikolić1 · Gordana Tamindžić1 · Žarko Ivanović ${ }^{2}$ \\ ${ }^{1}$ Institute of Field and Vegetable Crops, Maksima Gorkog 30, 21000 Novi Sad, Serbia \\ Institute for Plant Protection and Environment, Teodora Drajzera 9, 11000 Belgrade, Serbia
}

\begin{abstract}
Summary: During the routine quality control analysis on bean seeds in 2015, Fusarium fungal infection was observed on an average of $17 \%$ of the bean seed. The objective of this paper was isolation and identification of Fusarium sp. based on the pathogen's morphological and molecular characteristics. Morphological identification of Fusarium isolates was performed on PDA and CLA. DNA of 14 Fusarium sp. isolates was extracted directly from the mycelium $(\sim 100$ mg wet weight), with a Dneasy Plant Mini Kit (Qiagen, Hilden, Germany). Following DNA extraction, the translation elongation factor 1-alpha region was amplified by PCR with the primer pair EF1 and EF2. An amplicon of 700 bp was amplified in all tested isolates. Identification of one isolate was performed by sequencing the translation elongation factor EF-1a gene. Completed morphological and molecular characteristics of isolates, as well as the results of sequencing confirmed that Fusarium proliferatum was the causal agent of bean seed rot.

Key words: beans, EF-1a gene, Fusarium proliferatum, Phaseolus vulgaris, sequencing
\end{abstract}

\section{Introduction}

Species of Fusarium has been described as the most common seed-borne fungi of great economic importance which attacks and can be transmitted by bean seeds. Seed-borne pathogens are responsible for the reduction of seed growing energy and seed germination, and therefore can jeopardize production of this crop (Mahmoud et al., 2013; Jasnić et al., 2005; Pavlović et al., 2012). Lević et al. (2009) indicate that Fusarium species periodically cause significant diseases, especially the wilting type of disease, on onion, garlic, tomato, but there is a lack of information about Fusarium species associated with bean seed (Phaseolus vulgaris L.) in Serbia. The most common seed-borne fungi on dry beans are: Fusarium sp., Alternaria sp., Botrytis sp., Penicillium sp., Rhizopus sp., Cladosporium sp. and Trichotecium sp. (Domijan et al., 2005). The objective of this study was isolation and identification of the causal agent of bean seed rot based on the pathogen's morphological and molecular characteristics.

Corresponding author:

maja.ignjatov@ifvcns.ns.ac.rs

Acknowledgements:

This research was supported by the Ministry of Education, Science and Technological Development of the Republic of Serbia, project: TR31030 - Development of new vegetable varieties and hybrids for outdoor growing and greenhouses.

\section{Materials and Methods}

\section{Isolation and morphological characterization}

Bean seeds were immersed in $\mathrm{NaOCl}$ solution ( $1 \%$ available chlorine) for 5 minutes, and then drained. Seed subsamples (containing 400 seeds) were taken from 18 seed samples. Plating was performed aseptically and 10 seeds were placed onto blotter surface of each plate. Plates were incubated for 7 days at $25{ }^{\circ} \mathrm{C}$ in the dark. Observation of each seed was carefully performed under a stereo-microscope and the microscopic examination was done with different magnifications. The fragments of diseased seed were sterilized with $3 \% \mathrm{NaOCl}$ for 3 minutes, dried and placed on potato dextrose agar (PDA), and then incubated for seven days at $25{ }^{\circ} \mathrm{C}$. A total of 14 isolates of Fusarium spp. were obtained from the infected bean seed samples collected from storages and warehouses in Serbia. Fungi isolates were singlespored and sub-cultured, using single spore technique (Leslie and Summerell, 2006), on both PDA and Leaf carnation agar (CLA) for 7-10 days at $25{ }^{\circ} \mathrm{C}$, in alternating cycles of 12 hours light and 12 hours darkness. Morphological identification of Fusarium isolates was done on PDA and CLA according to the taxonomy of Nelson et al. (1983) and Leslie \& Summerell (2006). 


\section{Pathogenicity test}

Bean seeds (ten seeds of each sample/two repetition) were artificially infected by immersing seeds in spore suspension (du Toit \& Inglis, 2003). Plates were incubated at $25^{\circ} \mathrm{C}$ and examined on daily basis for 7-10 days. Fusarium isolates were re-isolated and subcultured on PDA. Seed treated with known strain Fu12 were used as the positive control. Non-treated seeds were used as the negative control.

\section{PCR and DNA sequencing}

To identify 14 representative strains, amplification of TEF- $1 \alpha$ gene, using polymerase chain reaction (PCR) was performed with the primer pair: EF1 and EF2 (O'Donnell et al., 1998), which directs the amplification of the 700-bp DNA fragment. Amplifications were carried out in a Mastercycler ep gradient $S$ thermal cycler (Eppendorf, Germany) under the following programs: - 35 repeated cycles: $94{ }^{\circ} \mathrm{C} 1 \mathrm{~min}, 53{ }^{\circ} \mathrm{C} 1$ min, $72^{\circ} \mathrm{C} 2 \mathrm{~min}$. The PCR mixture with a total volume of $25 \mu \mathrm{l}$ consisted of $2 \mathrm{x}$ Eppendorf Master Mix (Taq DNA polymerase $1.25 \mathrm{U}, 30 \mathrm{mM}$ Tris- $\mathrm{HCl}, 50 \mathrm{mM} \mathrm{KCl}$, $1.5 \mathrm{mM} \mathrm{MgCl}$; 0.1\% Igepal-CA630; 0.2 mM dNTP); 0.6 $\mu \mathrm{M}$ of each primer, and $1 \mu \mathrm{l}$ of fungal DNA. DNA fragments were amplified on the Eppendorf Mastercycler PCR device using the modified program by Abdel-Satar et al. (2003). The PCR products thus obtained were separated by electrophoresis on a $1 \%$ agarose gel over a period of 60 minutes using a constant voltage of $100 \mathrm{~V}$, after which they were observed on a UV-transilluminator. The appearance of fragments with an expected size of $700 \mathrm{bp}$ was considered a positive reaction. After completion of the reaction, PCR products were transferred to a pre-labelled $1.5 \mathrm{ml}$ tubes and sent to sequencing. Purification and sequencing of the amplified fragments was done in Company MACROGEN, Seoul, South Korea (http:// dna.macrogen.com). Sequences were analysed in the program FinchTV Version 1.4.0., and filed in the GenBank database under the National Centre for Biotechnology Information (NCBI).

\section{Phylogenetic analysis}

Manual corrections of aligned database, phylogenetic and molecular evolutionary analyses were conducted using MEGA 6 software package (Tamura et al., 2013). These gene sequences were assembled and edited using FINCHTV v.1.4.0 (http:// www.geospiza.com). Multiple alignments and comparisons with reference strains for each of the genes were performed using CLUSTALW integrated into MEGA 6 software (Tamura et al., 2013). The evolutionary history was inferred using the NeighborJoining method (Saitou \& Nei, 1987). The bootstrap consensus tree inferred from 1000 replicates was taken to represent the evolutionary history of the analysed taxa (Felsenstein, 1985). The evolutionary distances were computed using the Maximum Composite
Likelihood method (Tamura et al., 2004) and are presented as units of the number of base substitutions per site.

\section{Results and Discussion}

Morphological characterization of Fusarium species

During the routine quality control analysis on bean seeds in 2015, Fusarium fungal infection was observed on an average of $17 \%$ of the bean seed. Symptoms of Fusarium sp. on seeds appeared as white mycelium, usually with purple pigmentation around the infected seeds. Presence of Fusarium sp. was confirmed by microscopic examination of conidia. Pigments produced on PDA varied from light pink to dark red. Aerial mycelium was fast growing, with or without concentric rings, with an average growth rate of $8 \mathrm{~cm}$ in 7 days. On CLA microconidia were mostly in chain of single-celled microconidia, dimensions of 4-12 $\mu \mathrm{m} \times 2$ $3 \mu \mathrm{m}$. Macroconidia were hyaline, almost straight, mostly with 3 septate. The size of macroconidia averaged 20-42 $\mu \mathrm{m} \times 2-3 \mu \mathrm{m}$. All the isolates were classified as $F$. proliferatum based on morphological characteristics similar to $F$. proliferatum as reported by Leslie \& Summerell (2006). All 14 tested isolates were found to be pathogenic. The symptoms of seed rot developed after 10 days of incubation at $25^{\circ} \mathrm{C}$. Infected seeds were covered with white mycelium usually with red to purple pigmentation, on blotter, under the infected seeds. On non-treated bean seeds symptoms of seed rot were not recorded. After re-isolation on PDA and CLA, fungi were identified based on the colony characters and spore morphology.

$F$. proliferatum is a common pathogen infecting field and vegetable crops worldwide. To increase the yield of bean, growers need healthy quality seeds with high percentage of germination (Jasnić et al., 2005). According to Neergard (1997) many important diseases are caused by seed-borne fungi. Species of Fusarium has been described as the most common seed-borne fungi of great economic importance which attack and can be transmitted by vegetable seeds, but there is a general lack of data about fusarioses transmitted by bean seeds in Serbia.

\section{Sequencing and phylogenetic analysis}

Genetic analysis of the translation elongation factor $1-\alpha$ (TEF) sequence, confirmed that isolates originating from bean belong to $F$. proliferatum species showing $100 \%$ homology with $F$. proliferatum strain from GenBank (Accession number KM462983). TEF partial gene sequence of $F$. proliferatum was analysed to conduct a phylogenetic tree. Sequences generated in this study were added to the sequences of different Fusarium species selected from a BLAST search in NCBI GenBank for better understanding of their phylogenetic relationship (Geiser et al., 2004). A NJ tree constructed showed that the bean isolates were grouped together 
with next reference strains from data base: F. proliferatum JX065071, Gibberella intermedia JX065073, Gibberella fujikuroi var. intermedia AM404116, F. proliferatum KM462983, F. proliferatum AB725613, F. proliferatum JX118983 and F. thapsinum JX268969 (Fig. 1). Morphological identification of Fusarium species is time consuming and molecular methods provide precise identification (Ignjatov et al., 2012). Completed morphological and molecular characteristics of isolates, as well as results of sequencing confirmed that Fusarium proliferatum is the causal agent of bean seed rot. Using primers EF1 and EF2, a specific band at 700 bp was obtained by PCR for 14 isolates. This part of the genome sequence is considered to be highly significant information on species level for the entire Fusarium genus (Summerell et al., 2003; Geiser et al., 2004) and one isolate (P1) was identified by sequencing the translation elongation factor EF-1a gene. For better determination of this pathogen, this study included the use of molecular characters to revealed genetic similarity with different Fusarium taxa. This study based on analysis TEF gene sequences confirmed that strain originated from bean had 100\% homology to sequences of F. proliferatum strain KM462983 obtained from NCBI data base. In the previous studies TEF gene sequences were used to understand phylogenetic relationship among the members of the Fusarium group (Stępień et al., 2011; 2012).

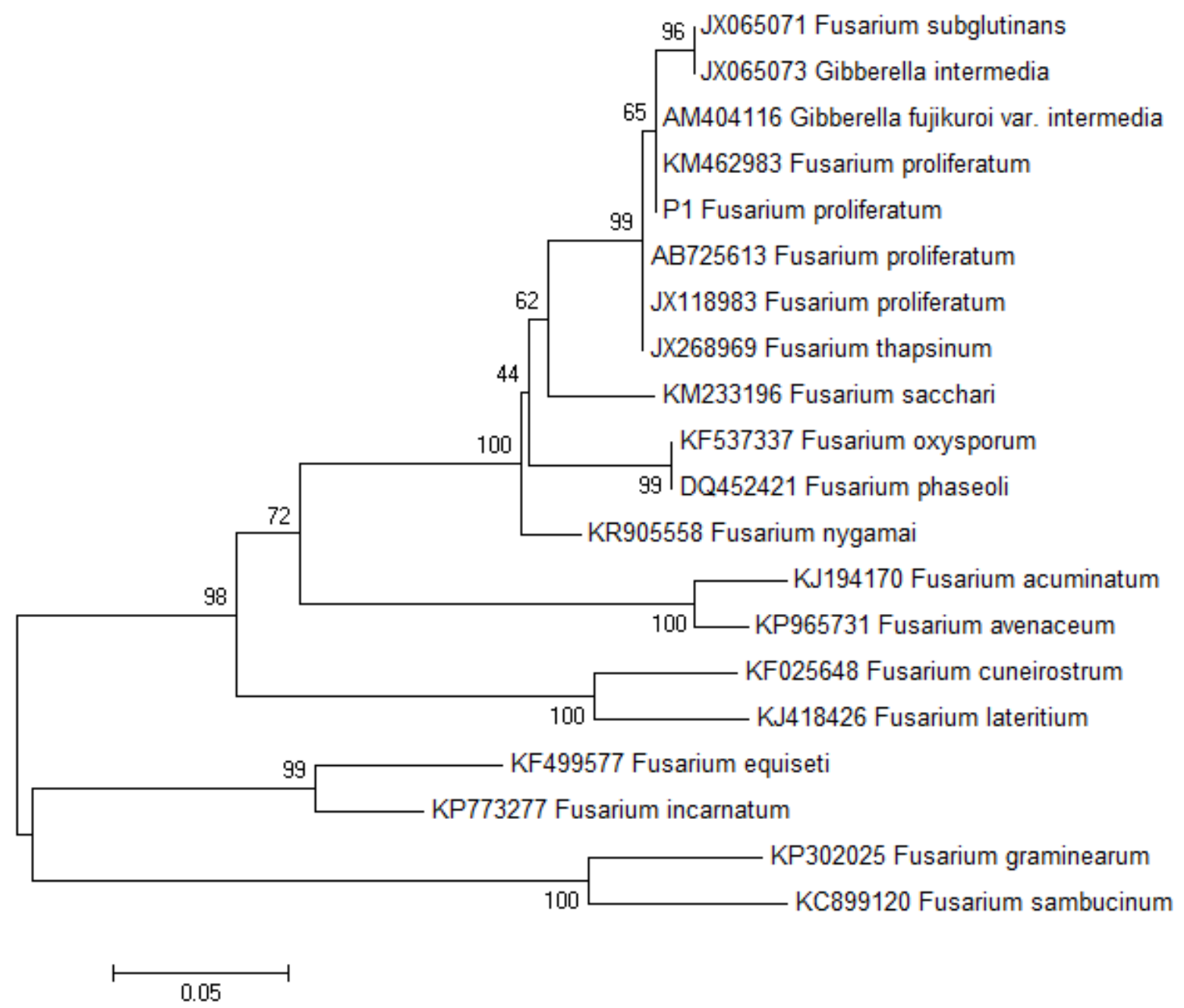

Figure 1. Phylogenetic tree based on Neighbour-Joining (NJ) analysis of TEF gene sequences for F. proliferatum isolates from bean and other Fusarium reference strains from NCBI data base. Bar - estimated nucleotide substitutions per site is 0.05 . 


\section{Conclusions}

Based on the morphological characteristics of fungal isolates, we confirmed presence of Fusarium sp. on bean seed. Completed morphological and molecular characteristics of isolates and sequencing results confirmed that Fusarium proliferatum is the causal agent of bean seed rot. Our study clearly revealed genetic differences of our isolates with other Fusarium species. The presence of this pathogen could reduce seed germination and decrease bean production in Serbia. These results will improve the base for the effective disease management strategies.

\section{References}

Abdel-Satar, M. A., Khalil, M. S., Mohmed, I. N., Abd-Elsalam, K. A., \& Verreet, J. A. (2003). Molecular phylogeny of Fusarium species by AFLP fingerprint. African Journal of Biotechnology, 2(3), $51-$ 55. doi: 10.5897/AJB2003.000-1010.

Domijan, A. M., Peracia, M., Cvjetković, B., Jurjević, Z., TopolovecPintarić, S., \& Ivić, D. (2005). Seed-borne fungi and contamination of dry beans (Phaseolus vulgaris L.) in the Republic of Croatia. Food and Chemical Toxicology, 43(3), 427-432.

du Toit, J. L., \& Inglis, D. A. (2003): Fusarium proliferatum pathogenic on onion bulbs in Washington. Plant Disease, 87, 750. doi 10.1094/PDIS.2003.87.6.750A

Felsenstein, J. (1985). Phylogenies and the comparative method. American Naturalist, 125(1), 1-15.

Geiser, D. M., der mar Jimenez-Gasco, M., Kang, S., Makalowska, I., Veeraraghavan, N., Ward, T. J.;

Zhang, N., Kuldau, G. A., \& O’Donnell, K. (2004). FUSARIUM-ID v.1.0 A DNA sequence database for identifying Fusarium. European Journal of Plant Pathology, 110, 473-479.

Ignjatov, M., Milošević, D., Nikolić, Z., Gvozdanović-Varga, J., Jovičić, D., \& Zdjelar, G. (2012). Fusarium oxysporum as causal agent of tomato wilt and fruit rot. Pesticidi i fitomedicina, 27(1), 25 31. DOI: 10.2298/PIF1201025I.

Jasnić, S., Vidić, M., Bagi, F., \& Đorđević, V. (2005). Pathogenicity of Fusarium species in soybean. Proceedings for Nature Sciences Matica Srpska, 109, 113-121.
Leslie, J. F., \& Summerell, B. A. (2006). The Fusarium Laboratory Manual. Ames, IA, USA: Blackwell Publishing Professional.

Lević, J., Stanković, S., Krnjaja, V., \& Bočarov-Stančić, A. (2009). Fusarium species: The occurrence and the importance in agricultural of Serbia. Proceedings for Nature Sciences, Matica Srpska, Novi Sad, 116, 33-48.

Mahmoud, S. Y. M., Hosseny, M. H., EL-Shaikh, K. A. A., Obiadalla, A. H. A., \& Mohamed, Y. A. (2013). Seed borne fungal pathogens associated with common bean (Phaseolus vulgaris L.) seeds and their impact on germination. Journal of Environmental Studies [JES], 11, 19-26.

Neergard, P. (1997). Seed Pathology. London, UK: MacMillan Press.

Nelson, P. E., Tousson, T. A., \& Marasas, W. F. O. (1983). Fusarium species. An illustrated manual for identification. Pennsylvania, USA: The Pennsylvania State University Press.

O'Donnell, K., Cigelnik, E., \& Nirenberg, H. I. (1998). Molecular systematic and phylogeography of the Gibberella fujikuroi species complex. Mycologia, 90, 465-493.

Pavlović, S., Stević, T., Starović, M., Jošić, D., Popović, T., Ignjatov, M., \& Stojanović, S. (2012). Gibberella zeae na semenu kantariona u Srbiji. Ratarstvo i pourtarstvo, 49(1), 58-62. doi:10.5937/ratpov491164.

Saitou, N., \& Nei, M. (1987). The Neighbor-Joining method: A new method for reconstructing phylogenetic trees. Molecular Biology and Evolution, 4, 406-425.

Stępień, Ł., Koczyk, G., \& Waśkiewicz, A. (2011). Genetic and phenotypic variation of Fusarium proliferatum isolates from different host species. Journal of Applied Genetics, 52, 487-496. doi: 10.1007/s13353-011-0059-8.

Stępień, L., Gromadzka, K., \& Chełkowski, J. (2012). Polymorphism of mycotoxin biosynthetic genes among Fusarium equiseti isolates from Italy and Poland. Journal of Applied Genetics, 53, 227 -236. doi: 10.1007/s13353-012-0085-1.

Summerell, B. A., Salleh, B., \& Leslie, J. F. (2003). A utilitarian approach to Fusarium identification. Plant Disease, 87, 117-128.

Tamura, K., Nei, M., \& Kumar, S. (2004). Prospects for inferring very large phylogenies by using the Neighbor-Joining method. Proceedings of the National Academy of Sciences of the United States of America, 101, 11030-11035.

Tamura, K., Stecher, G., Peterson, D., Filipski, A., \& Kumar, S. (2013). MEGA6: Molecular Evolutionary Genetics Analysis version 6.0. Molecular Biology and Evolution, 30, 2725-2729. doi: $10.1093 / \mathrm{molbev} / \mathrm{mst} 197$.

\section{Pojava, identifikacija i filogenetska analiza Fusarium proliferatum prouzrokovača truleži semena pasulja (Phaseolus vulgaris L.) u Srbiji}

\section{Maja Ignjatov · Tatjana Popović · Dragana Milošević · Mirjana Vasić . Zorica Nikolić · Gordana Tamindžić · Žarko Ivanović}

Sažetak: Tokom rutinske kontrole kvaliteta semena pasulja (Phaseolus vulgaris L.) u 2015. godini ustanovljeno je prisustvo Fusarium sp. u visokom procentu, u proseku 17\%. Cilj ovog rada bio je izolacija i identifikacija prouzrokovača truleži semena pasulja, na osnovu morfoloških i molekularnih karakteristika patogena. Odgajivačke karakteristike 14 odabranih izolata ocenenjene su na PDA i CLA podlogama. Ekstrakcija DNK 14 odabranih izolata obavljena je direktno iz $100 \mathrm{mg}$ sveže micelije, korišćenjem Dneasy Plant Mini Kit (Qiagen, Hilden, Nemačka). Amplifikacija DNK obavljena je pomoću PCR korišćenjem para prajmera EF1 i EF2. U svim proučavanim izolatima formirani su amplikoni veličine 700 bp. Identifikacija jednog odabranog izolata izvršena je sekvenciranjem translacionog faktora EF-1a gena. Na osnovu dobijenih rezultata ustanovljeno je da je prouzrokovač truleži semena pasulja Fusarium proliferatum.

Ključne reči: EF-1a gen, Fusarium proliferatum, pasulj, Phaseolus vulgaris, sekvenciranje 